\title{
The effects of different plasma insulin concentrations on lipolytic and ketogenic responses to epinephrine in normal and Type 1 (insulin-dependent) diabetic humans
}

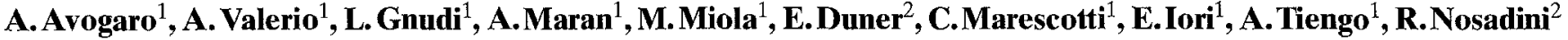 \\ ${ }^{1}$ Cattedra di Malattie del Ricambio, ${ }^{2}$ Cattedra di Patologia Medica I, Universita' di Padova, Italy
}

Summary. This study was performed to verify: (1) the ability of different insulin concentrations to restrict the lipolytic and ketogenic responses to exogenous epinephrine administration; (2) whether the ability of insulin to suppress the lipolytic and ketogenic responses during epinephrine administration is impaired in Type 1 (insulin-dependent) diabetic patients. Each subject was infused on separate occasions with insulin at rates of $0.2,0.4$, and $0.8 \mathrm{mU} \cdot \mathrm{kg}^{-1} \cdot \mathrm{min}^{-1}$ while normoglycaemic. To avoid indirect adrenergic effects on endocrine pancreas secretions, the so-called "islet clamp" technique was used. Rates of appearance of palmitic acid, acetoacetate, and 3-hydroxybutyrate were simultaneously measured with an infusion of ${ }^{13} \mathrm{C}$-labelled homologous tracers. After a baseline observation period epinephrine was exogenously administered at a rate of $16 \mathrm{ng} \cdot \mathrm{kg}^{-1} \cdot \mathrm{min}^{-1}$. At low insulin levels $(20 \mu \mathrm{U} / \mathrm{ml})$ the lipolytic response of comparable magnitude was detected in normal and Type 1 diabetic patients. However, the ketogenic response was significantly higher in Type 1 diabetic patients. During epinephrine administration, similar plasma glucose increments were observed in the two groups (from $4.74 \pm 0.53$ to $7.16 \pm 0.77 \mathrm{mmol} / 1 \quad(p<0.05)$ in Type 1 diabetic patients and from $4.94 \pm 0.20$ to $7.11 \pm$ $0.38 \mathrm{mmol} / 1(p<0.05)$ in normal subjects, respectively). At intermediate insulin levels $(35 \mu \mathrm{U} / \mathrm{ml})$ no significant dif- ferences were found between Type 1 diabetic patients and normal subjects, whereas plasma glucose levels rose from $4.98 \pm 0.30$ to $6.27 \pm 0.66 \mathrm{mmol} / \mathrm{l}(p<0.05)$ in Type 1 diabetic patients, and from $5.05 \pm 0.13$ to $6.61 \pm 0.22 \mathrm{mmol} / 1(p<0.05)$ in normal subjects. At high insulin levels $(70 \mu \mathrm{U} / \mathrm{ml})$ the lipolytic response was detectable only in Type 1 diabetic patients; the ketogenic response was reduced in both groups. During the third clamp, a significant rise in plasma glucose concentration during epinephrine infusion was observed in both groups. In conclusion this study shows that at low insulin levels Type 1 diabetic patients show an increased ketogenic response to epinephrine, despite their normal nonesterified fatty acid response. Instead, high insulin levels are able to restrict the ketogenic response to epinephrine in both normal and Type 1 diabetic subjects, although there is a still detectable lipolytic response in the latter. In the presence of plasma free insulin levels that completely restrict the ketogenic response in the same group, there is still a distinct glycaemic response. Plasma insulin levels in Type 1 diabetic patients are a major determinant of the metabolic response to epinephrine.

Key words: Ketone bodies, non-esterified fatty acids, epinephrine, insulin, stable isotopes.
Ketone bodies (KB) are important oxidizable substrates for the brain [1], heart [2], and muscle tissue [3], as long as glucose uptake is adequate in providing a substantial oxaloacetate pool [4]. KB production in the liver depends on non-esterified fatty acid (NEFA) availability and hence on lipolysis [5]. Several hormones can increase or decrease the rate of lipolysis in the adipocytes. It is therefore evident that the NEFA concentration in plas$\mathrm{ma}$, and hence $\mathrm{KB}$ production, are controlled by several hormones. Insulin is probably the major physiological antilipolytic hormone in adipose tissue, whereas catecholamine is one of the most powerful lipolytic agents [6].
In vitro studies have shown that insulin can antagonize the lipolytic action of epinephrine in several ways: by decreasing the intracellular level of cAMP [7], modifying the number of $\beta$ adrenoreceptors in fat cells [8], and inhibiting epinephrine-induced fatty acid transport across the adipocyte membranes $[9,10]$. It has recently been demonstrated that adipocytes obtained from Type 1 (insulin-dependent) diabetic subjects display enhanced sensitivity of epinephrine-induced lipolysis [11].

It has also been shown in vivo that insulin secretion normally limits the glycaemic but not the lipolytic or ketogenic responses to epinephrine in humans. However, these observations were obtained at basal plasma insulin 
levels [12]. Furthermore, during euglycaemic hyperinsulinaemic clamp, the effects of epinephrine on plasma NEFA content were overridden only by a pharmacologically high insulin concentration [13]. In this regard, there is evidence that excessively high insulin infusion increases the sympathetic nervous system activity in the absence of changes in plasma glucose [14]. As a consequence of this sympathetic overactivity, plasma epinephrine concentration in plasma might not be steady in a given experimental condition involving simultaneous exogenous infusion of this hormone and stimulation of its endogenous secretion by pharmacologic hyperinsulinaemia.

In the light of these observations, we performed the present study to verify: 1 ) the efficacy of different plasma insulin concentrations, spanning physiologic levels, to restrain lipolytic and ketogenic responses to exogenous epinephrine administration;2) the ability of insulin to suppress lipolytic and ketogenic responses in Type 1 diabetic patients and in control subjects, using simultaneous kinetic analysis of precursors (NEFA) and products (KB).

\section{Subjects and methods}

\section{Subjects}

Five normal subjects (four male and one female) and five Type 1 diabetic patients (four male and one female) gave their written consent to participate in this study, which was approved by the Ethical Committee of the City Hospital of Padova. The mean ( \pm SEM) ages of both patients and control subjects were $25 \pm 2$ and $23 \pm 3$ years, respectively. All subjects had a normal body mass index $\left(21 \pm 2 \mathrm{~kg} / \mathrm{m}^{2}\right.$ in Type 1 patients and $22 \pm 3$ in normal subjects). The patients had been Type 1 diabetic for an average of $12 \pm 2$ years and were selected for the absence of nephropathy, proliferative retinopathy, autonomic neuropathy, hypertension, overt heart disease, anaemia and drug use other than insulin. All had documented previous episodes of ketoacidosis. Each Type 1 diabetic patient normally received three insulin injections per day: regular insulin at 08.00 hours $(13 \pm 5 \mathrm{IU})$, 12.00 hours $(14 \pm 7 \mathrm{IU}), 19.00$ hours $(11 \pm 5 \mathrm{IU})$, and long-acting insulin at 19.00 hours $(15 \pm 7 \mathrm{IU})$. The study was performed at the Department for Metabolic Diseases of the University of Padova.

\section{Materials}

$\left[1-{ }^{13} \mathrm{C}_{1}\right]$ palmitic acid $\left(90 \%{ }^{13} \mathrm{C}_{1}\right)$ was supplied by Merck Isotopes Company (Montreal, Canada) and prepared for human use as previously described [15]. Ethyl $\left[1,3-{ }^{13} \mathrm{C}_{2}\right]$ acetoacetate $\left(98 \%{ }^{13} \mathrm{C}_{2}\right), \mathrm{D}-3-$ hydroxy $\left[1,2,3,4,{ }^{13} \mathrm{C}_{4}\right]$ butyrate $\left(92 \%{ }^{13} \mathrm{C}_{4}\right)$ and D-3-hydroxy $[1,2,3,4-$ $\left.{ }^{13} \mathrm{C}_{4}, 2,2,3,-{ }^{2} \mathrm{H}_{4}\right]$ butyrate as internal standard were provided by Tracer Technology, Inc. (Cambridge, Mass., USA). ${ }^{13} \mathrm{C}_{2}$ acetoacetate was prepared from the ethyl ester according to the same method previously described [16]. Prior to use, each material was tested for chemical and isotopic purity by conventional chemical, enzymatic, gas chromatographic and mass spectrometric methods. Sterility was verified by bacteriologic analysis, and the materials were shown to be pyrogen-free by licenced commercial pyrogen testing in rabbits.

\section{Procedural methods}

Subjects were studied in the post-absorptive state after an overnight fast. They followed a weight-maintaining diet containing at least $300 \mathrm{~g}$ of carbohydrate for 7 days prior to the test. In Type 1 diabetic patients the last intermediate- or long-acting insulin injection was administered $48 \mathrm{~h}$ before examination. Diabetes was thereafter managed with four daily regular insulin injections at $08.00,12.00$, 18.00 , and 22.00 hours. Mean daily plasma glucose during the $48 \mathrm{~h}$ prior to the study was $7.8 \pm 0.9 \mathrm{mmol} / 1$. From 17.00 hours on the day before the study plasma glucose concentrations were maintained between 5.3 and $6.1 \mathrm{mmol} / 1$ with a variable i. v. insulin infusion. The insulin infusion rate to maintain plasma glucose within normal range was $0.11 \pm 0.03 \mathrm{mU} \cdot \mathrm{kg}^{-1} \cdot \mathrm{min}^{-1}$. Plasma glucose was determined every 30 min with a Beckman glucose analyzer (Fullerton, Calif., USA). Each subject was studied in the supine position. Vascular access for infusion and sampling was established at least 30 min prior to sampling. A 19-gauge needle was inserted into a dorsal hand vein in a retrograde fashion and the hand was placed in a heated box (50$55^{\circ} \mathrm{C}$ ) to obtain arterialized venous blood. An 18-gauge infusion catheter was placed in a contralateral forearm vein and kept patent by a controlled infusion of $0.9 \% \mathrm{NaCl}$ solution. In each test, in order to avoid indirect adrenergic effects on Alpha and Beta pancreatic cells in the presence of high plasma epinephrine concentrations, the socalled "islet clamp" technique was performed by administering respectively the following substances: somatostatin (Serono, Milan, Italy) at a rate of $250 \mu \mathrm{g} / \mathrm{h}$ : glucagon (Eli Lilly Co., Indianapolis, Ind., USA) (0.6 ng $\left.\cdot \mathrm{kg}^{-1} \cdot \mathrm{min}^{-1}\right)$, recombinant DNA human growth hormone (Protropin; Genentech, San Francisco, Calif., USA) $\left(9 \mathrm{ng} \cdot \mathrm{kg}^{-1} \cdot \min ^{-1}\right)$, and human soluble insulin at variable rates. Somatostatin, glucagon, and growth hormone were suspended in the same syringe containing $1 \%$ human serum albumin in $0.9 \% \mathrm{NaCl}$ and infused with a calibrated Harvard pump. This solution was prepared on the day of the study and the hormone concentration was verified in the infusate when testing was over. The insulin was dissolved in a separate syringe containing $0.9 \% \mathrm{NaCl}$ and $2 \mathrm{ml}$ of the patient's blood. This solution was made up on the morning of the test and was infused by a calibrated Harvard pump. Plasma glucose was checked at 5-min intervals. When the plasma glucose level was stable for at least $60 \mathrm{~min}$ the insulin infusion rate was fixed and kept constant throughout the remainder of the test.

Each subject was studied on four occasions. The insulin infusion rates necessary to maintain plasma glucose within the normal range during the night were replaced by four different insulin infusion rates. In the control clamp study, insulin $\left(0.13 \pm 0.04 \mathrm{mU} \cdot \mathrm{kg}^{-1}\right.$. $\mathrm{min}^{-1}$ ) was infused to replace the basal hormone concentration and no epinephrine was administered, in order to assess the NEFA and $\mathrm{KB}$ steady-state concentrations during the whole study period. In the first clamp, insulin was infused at a rate of $0.2 \mathrm{mU} \cdot \mathrm{kg}^{-1} \cdot \mathrm{min}^{-1}$. In the second clamp, it was infused at a rate of $0.4 \mathrm{mU} \cdot \mathrm{kg}^{-1} \cdot \mathrm{min}^{-1}$, and in the third clamp, the rate was $0.8 \mathrm{mU} \cdot \mathrm{kg}^{-1} \cdot \mathrm{min}^{-1}$.

During the first, second, and third clamps, glucose was infused to maintain plasma glucose levels between $4.5-5 \mathrm{mmol} / \mathrm{l}$. Once the plasma glucose concentration was steady for at least $1 \mathrm{~h}$ for a given insulin concentration, a continuous simultaneous infusion of [1. $\left.{ }^{13} \mathrm{C}_{1}\right]$ palmitate, $\left[1,3-{ }^{13} \mathrm{C}_{2}\right]$ acetoacetate, and $\left[1,2,3,4-{ }^{13} \mathrm{C}_{4}\right] 3$-hydroxybutyrate was started (Time -20 in the figures). The concentration of each isotope in the infusate was checked by the reverse isotope dilution technique at the end of each experiment. The rate of infusion of natural palmitate present in the $25 \%$ human serum albumin solution was negligible $(<1 \%$ ), when compared to the total palmitate inflow.

After a 1-h equilibration period, during which tracer concentrations were allowed to achieve steady-state $[16,17]$, a set of baseline samples was obtained. At the end of the baseline sampling period, epinephrine was infused at a rate of $16 \mathrm{ng} \cdot \mathrm{kg}^{-1} \cdot \mathrm{min}^{-1}$ for $80 \mathrm{~min}$. To avoid hypoglycaemia, when the epinephrine infusion was started, the glucose infusion was continued at the same rate which had allowed plasma glucose clamping during the baseline observation period (Fig. 1). Five blood samples were then obtained at 15-min intervals during epinephrine infusion. The epinephrine infusion rate of $16 \mathrm{ng} \cdot \mathrm{kg}^{-1} \cdot \mathrm{min}^{-1}$ was chosen because distinct lipolytic and ketogenic plasma epinephrine levels [18] simultaneously avoiding pharmacologically high levels of the hormone. The epinephrine infusate was prepared in $0.9 \% \mathrm{NaCl}$ with the addition of ascorbic acid, $0.5 \mathrm{mg} / \mathrm{ml}$ of infusate, to prevent oxidation. Blood pressure and heart rate were checked after each specimen was withdrawn, before and during epinephrine infusion. Studies on a given subject were separated by at least 2 weeks, and randomly performed. 


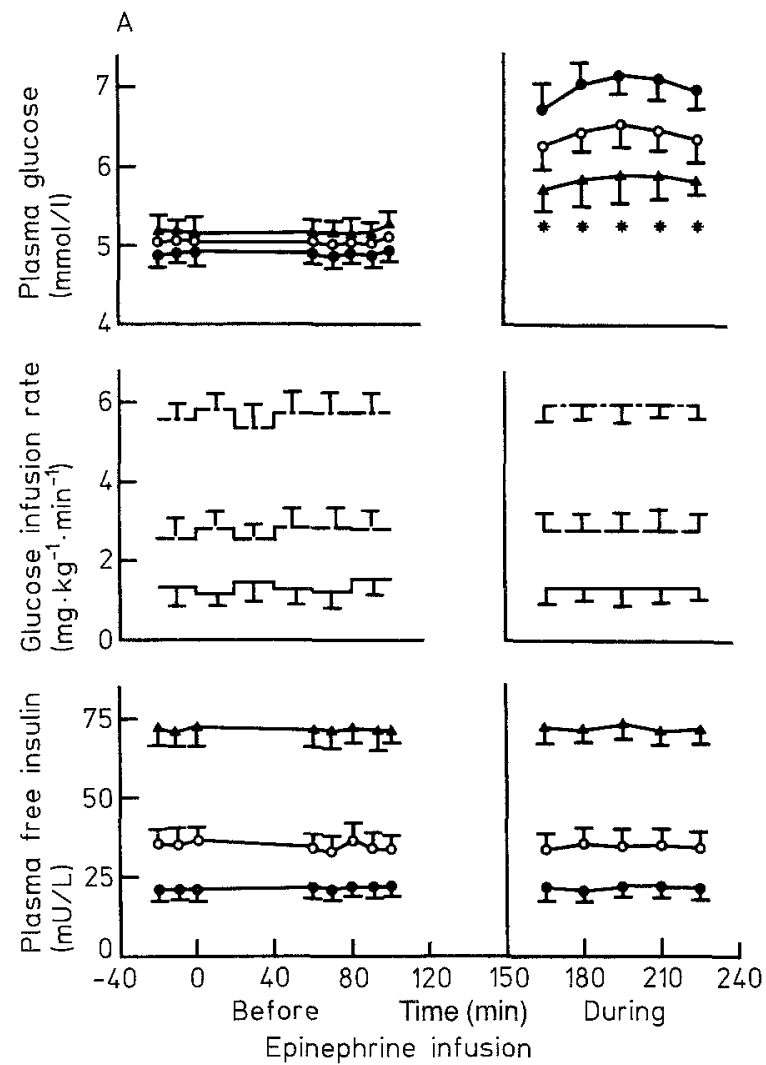

Fig.1A,B. Mean ( \pm SEM) plasma glucose concentration (top panel); exogenous glucose requirements (middle panel); plasma free insulin (lower panel) during the first $(\bullet)$, second $(0-0)$ and third

\section{Analytical methods}

Plasma glucose was measured on a Beckman glucose analyzer. Blood lactate and glycerol were measured using a fluorimetric technique [19]. Circulating plasma palmitate concentration and palmitate ${ }^{13} \mathrm{C}$ enrichment were determined by isotope dilution gas chromatography mass-spectrometry (GC-MS), using $[5,5,6,6-$ ${ }^{2} \mathrm{H}_{4}$ ]palmitate as internal standard, according to previous methods [20]. The total NEFA concentration was determined with a gas chromatographic technique [21]. Quantitation of individual blood KB, acetoacetate (AcAc) and 3-hydroxybutyrate (3-BOH) was performed according to published methods [22].

Plasma epinephrine and norepinephrine concentrations were measured using HPLC [23]. The intra-assay coefficient of variation for epinephrine determination was $12 \pm 2 \%$ and $13 \pm 2 \%$ for norepinephrine, respectively. The inter-assay coefficient of variation was $14 \pm 4 \%$ for epinephrine, and $15 \pm 2 \%$ for norepinephrine. Plasma growth hormone [24], free insulin, and C-peptide [25] were measured by polyclonal RIA. To minimize cross-reacting high molecular weight non-glucagon species, plasma glucagon was measured by double antibody RIA [26].

${ }^{13} \mathrm{C}$ enrichment of circulating $\mathrm{AcAc}$ and $3-\mathrm{BOH}$ were measured after extraction of the ketones into ethylacetate from the neutralized perchloric filtrate of plasma, as described [22].

\section{Data analysis}

The rate of appearance of palmitic acid was determined using steady-state calculations during the baseline observation period and non-steady-state calculations during the epinephrine stimulated period. For the non-steady-state equations, an effective volume of distribution of $90 \mathrm{ml} / \mathrm{kg}$ was chosen, as suggested by Jensen et al.

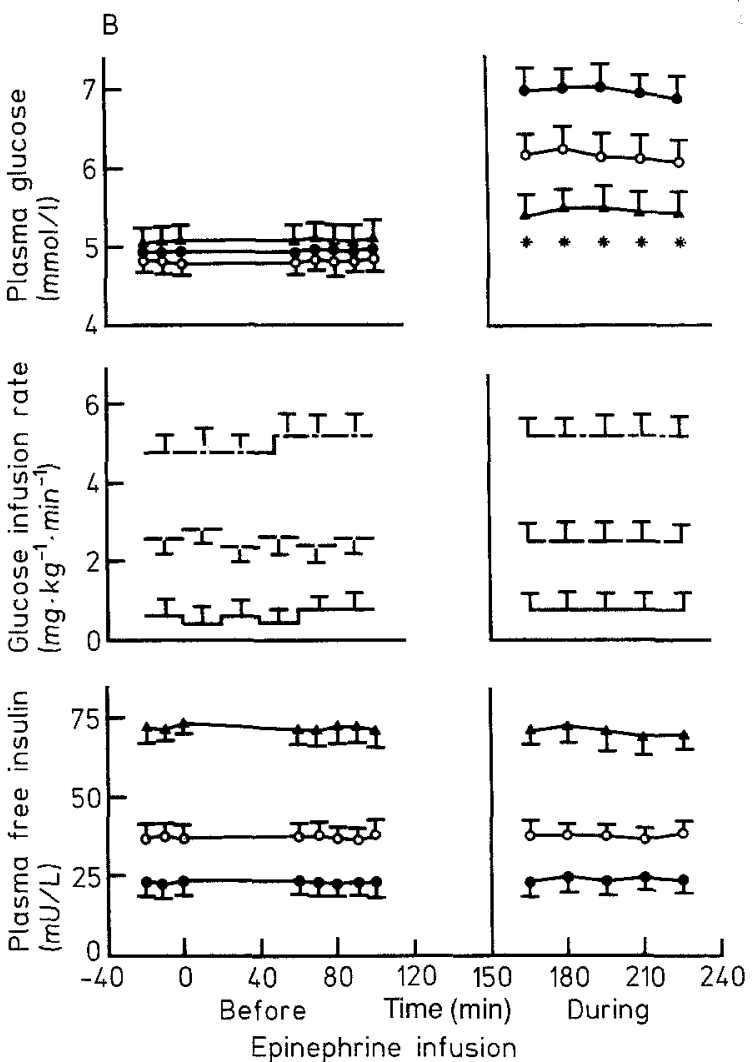

clamp ( $\mathbf{A})$ before and during epinephrine infusion in normal subjects (A) and diabetic patients (B). Asterisks: statistical significance between control period and epinephrine stimulated periods

[27]. The kinetic parameters of $\mathrm{KB}$ were calculated from the tracer mass/tracee mass ratio [28] and modified for non-steady-state according to Keller et al. [29]. All kinetic parameters are expressed as $\mu \mathrm{mol} \cdot \mathrm{kg}^{-1} \cdot \mathrm{min}^{-1}$.

\section{Statistical analysis}

Analysis of variance was used to estimate the differences between the groups, and between baseline data and the epinephrine-stimulated periods. The Wilcoxon test was used to analyse significant differences between groups in substrate and rate of appearance increments during epinephrine administration.

\section{Results}

Plasma glucose, free insulin and C-peptide concentrations (Fig. 1, and Tables 1 and 2)

During the control study plasma glucose remained stable at $4.57 \pm 0.41 \mathrm{mmol} / \mathrm{l}$ in Type 1 diabetic subjects. During epinephrine infusion, plasma glucose increased from $4.74 \pm 0.53$ to $7.16 \pm 0.77 \mathrm{mmol} / 1 \quad(p<0.05)$ in the first clamp, from $4.98 \pm 0.30$ to $6.27 \pm 0.66(p<0.05)$ in the second, and from $4.81 \pm 0.50$ to $5.66 \pm 0.55(p<0.05)$ in the third. Free insulin concentrations increased from $14 \pm 3 \mu \mathrm{U} / \mathrm{ml}$ during the control study to $22 \pm 5(p<0.05)$ during the first clamp, $34 \pm 11(p<0.01)$ during the second, and $73 \pm 16(p<0.01)$ during the third. 
Table 1. Metabolic, hormonal, and cardiovascular parameters during baseline, and during euglycaemic hyperinsulinaemic islet clamps in normal subjects

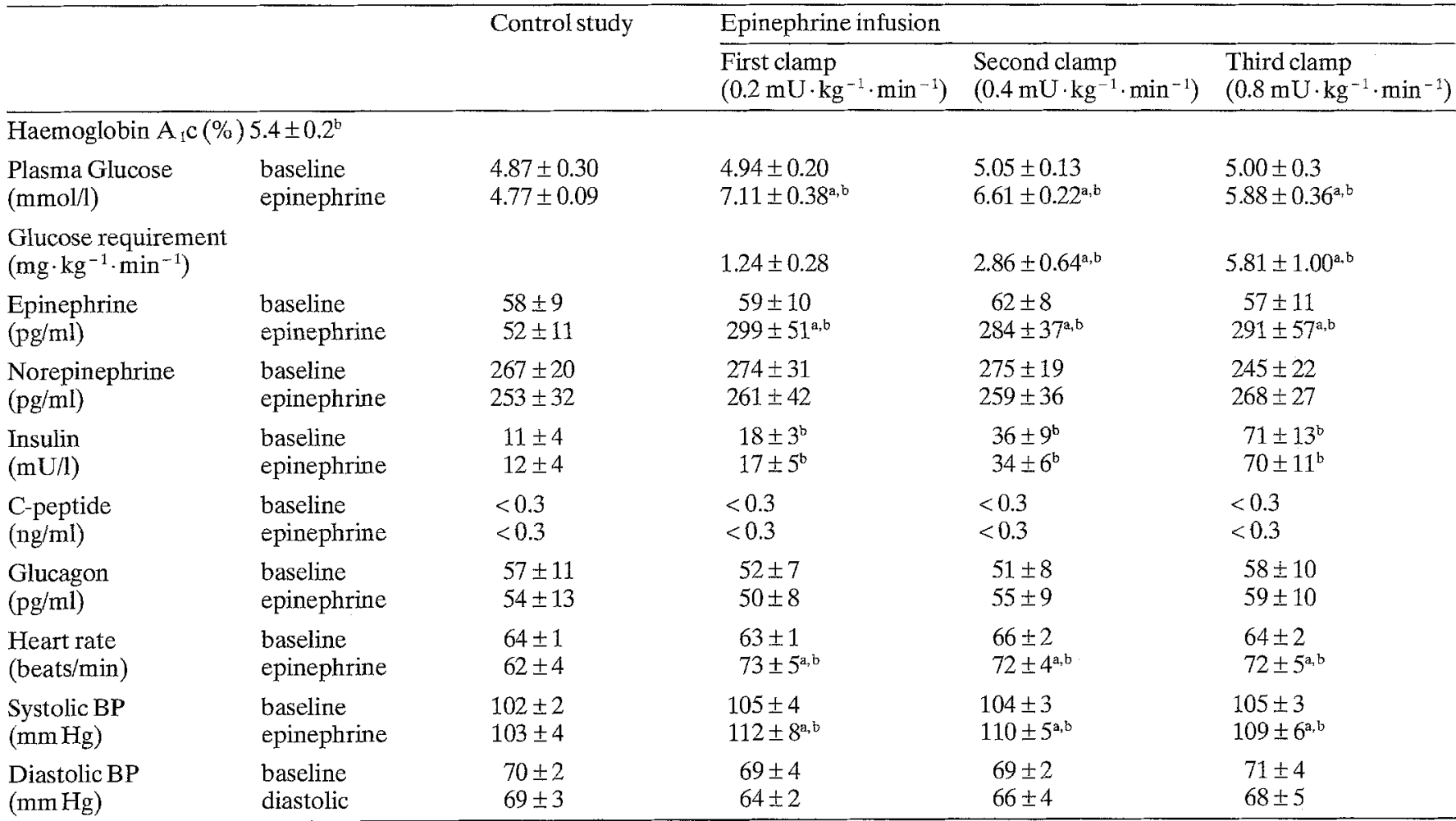

a Statistically different from baseline (at least $p=0.05$ )

b Statistically different from control study (at least $p=0.05$ )

BP, Blood pressure; C-peptide $1 \mathrm{nmol} / 1=3.02 \mathrm{ng} / \mathrm{ml}$; Insulin $1 \mathrm{pmol} / 1=0.167 \mathrm{lU} / \mathrm{ml}$; Epinephrine $1 \mathrm{pmol} / \mathrm{h}=0.183 \mathrm{pg} / \mathrm{ml}$; Norepinephrine $1 \mathrm{nmol} / \mathrm{l}=169 \mathrm{pg} / \mathrm{ml}$; Glucagon = $1 \mathrm{ng} / \mathrm{l}=1 \mathrm{pg} / \mathrm{ml}$

During the control study, plasma glucose was $4.87 \pm 0.30 \mathrm{mmol} / \mathrm{l}$ in normal subjects. During epinephrine infusion, plasma glucose increased from $4.94 \pm 0.20$ to $7.11 \pm 0.38 \mathrm{mmol} / \mathrm{l}(p<0.05)$ during the first clamp, from $5.05 \pm 0.13$ to $6.61 \pm 0.22(p<0.05)$ in the second, and from $5.00 \pm 0.31$ to $5.88 \pm 0.36(p<0.05)$ in the third. During the control study, free insulin concentrations ranged from $11 \pm 4$ to $12 \pm 4 \mu \mathrm{U} / \mathrm{ml}$ (NS). During the first, second, and third clamps free insulin concentrations increased to $18 \pm 3(p<0.05), 36 \pm 9(p<0.01)$, and $71 \pm 13(p<0.01)$ $\mu \mathrm{U} / \mathrm{ml}$ respectively. Glucose requirement (Fig. 1) was significantly higher during the second and the third clamps in both normal and Type 1 diabetic subjects, but no statistically significant differences were observed between the two groups. Plasma C-peptide levels were completely inhibited during "islet clamp" studies (Tables 1 and 2).
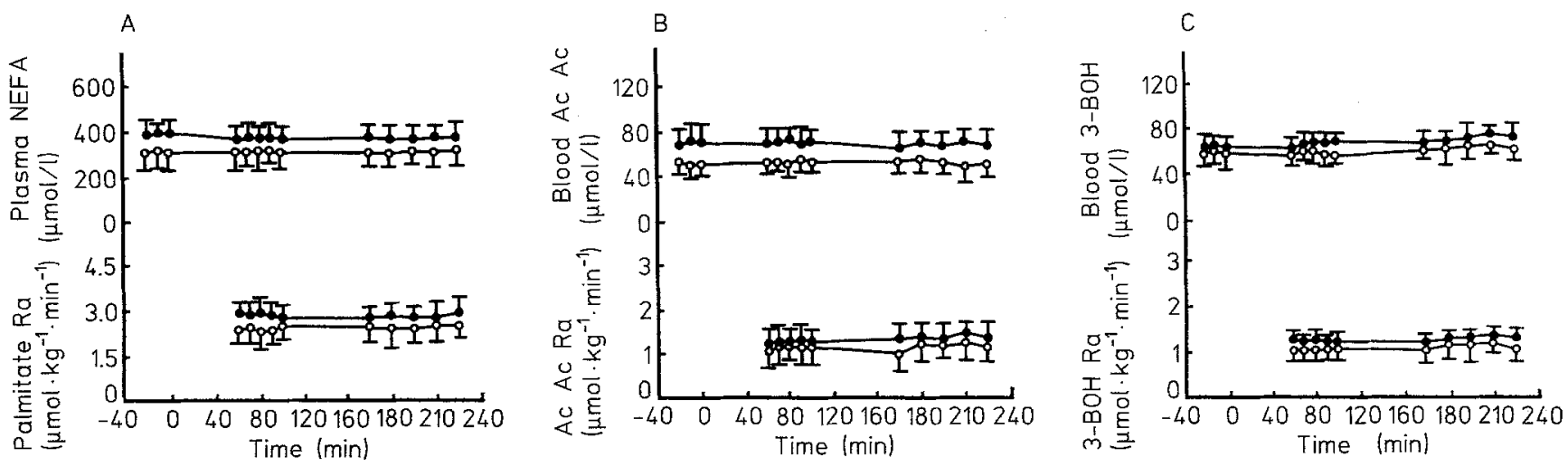

Fig. 2A-C. A Top panel. Mean ( \pm SEM) plasma non-esterified fatty acid (NEFA) concentration during control study. Bottom panel. Mean ( \pm SEM) palmitic acid rate of appearance during control study. B Top panel. Mean ( \pm SEM) blood acetoacetate (AcAc) concentration during control study. Bottom panel. Mean ( \pm SEM)
AcAc rate of appearance ( $\mathrm{Ra})$ during control study. C Top panel. Mean $( \pm$ SEM) blood 3-hydroxybutyrate (3-BOH) concentration during control study. Bottom panel. Mean ( \pm SEM) 3-BOH rate of appearance ( $\mathrm{Ra}$ ) during control study. Normal subjects $O-O$; diabetic patients 
Table 2. Metabolic, hormonal, and cardiovascular parameters during baseline, and during euglycaemic hyperinsulinaemic islet clamps in Type 1 (insulin-dependent) diabetic patients

\begin{tabular}{|c|c|c|c|c|c|}
\hline & & \multirow[t]{2}{*}{ Control study } & \multicolumn{3}{|l|}{ Epinephrine infusion } \\
\hline & & & $\begin{array}{l}\text { First clamp } \\
\left(0.2 \mathrm{mU} \cdot \mathrm{kg}^{-1} \cdot \mathrm{min}^{-1}\right)\end{array}$ & $\begin{array}{l}\text { Second clamp } \\
\left(0.4 \mathrm{mU} \cdot \mathrm{kg}^{-1} \cdot \mathrm{min}^{-1}\right)\end{array}$ & $\begin{array}{l}\text { Third clamp } \\
\left(0.8 \mathrm{mU} \cdot \mathrm{kg}^{-1} \cdot \mathrm{min}^{-1}\right)\end{array}$ \\
\hline \multicolumn{6}{|c|}{ Haemoglobin $\mathrm{A}_{1} \mathrm{c}(\%) 8.4 \pm 7^{\mathrm{b}}$} \\
\hline $\begin{array}{l}\text { Plasma glucose } \\
(\mathrm{mmol} / \mathrm{l})\end{array}$ & $\begin{array}{l}\text { baseline } \\
\text { epinephrine }\end{array}$ & $\begin{array}{l}4.57 \pm 0.41 \\
4.51 \pm 0.52\end{array}$ & $\begin{array}{l}4.74 \pm 0.53 \\
7.16 \pm 0.77^{\mathrm{a}, \mathrm{b}}\end{array}$ & $\begin{array}{l}4.98 \pm 0.35 \\
6.27 \pm 0.66^{\mathrm{a}, \mathrm{b}}\end{array}$ & $\begin{array}{l}4.81 \pm 0.52 \\
5.66 \pm 0.55^{a, b}\end{array}$ \\
\hline $\begin{array}{l}\text { Glucose requiren } \\
\left(\mathrm{mg} \cdot \mathrm{kg}^{-1} \cdot \mathrm{min}^{-1}\right)\end{array}$ & & & $0.81 \pm 0.31$ & $2.54 \pm 0.18^{\mathrm{b}}$ & $5.12 \pm 0.64^{b}$ \\
\hline $\begin{array}{l}\text { Epinephrine } \\
(\mathrm{pg} / \mathrm{ml})\end{array}$ & $\begin{array}{l}\text { baseline } \\
\text { epinephrine }\end{array}$ & $\begin{array}{l}63 \pm 17 \\
61 \pm 13\end{array}$ & $\begin{array}{c}55 \pm 12 \\
287 \pm 43^{\mathrm{a}}\end{array}$ & $\begin{array}{c}67 \pm 13 \\
279 \pm 37^{\mathrm{a}}\end{array}$ & $\begin{array}{c}56 \pm 13 \\
291 \pm 52^{\mathrm{a}, \mathrm{b}}\end{array}$ \\
\hline $\begin{array}{l}\text { Norepinephrine } \\
(\mathrm{pg} / \mathrm{ml})\end{array}$ & $\begin{array}{l}\text { baseline } \\
\text { epinephrine }\end{array}$ & $\begin{array}{l}235 \pm 23 \\
229 \pm 41\end{array}$ & $\begin{array}{l}243 \pm 27 \\
248 \pm 36\end{array}$ & $\begin{array}{l}253 \pm 16 \\
251 \pm 19\end{array}$ & $\begin{array}{l}231 \pm 24 \\
241 \pm 29\end{array}$ \\
\hline $\begin{array}{l}\text { Insulin } \\
(\mathrm{mU} / \mathrm{l})\end{array}$ & $\begin{array}{l}\text { baseline } \\
\text { epinephrine }\end{array}$ & $\begin{array}{l}14 \pm 3 \\
16 \pm 2\end{array}$ & $\begin{array}{l}22 \pm 5^{b} \\
24 \pm 6^{b}\end{array}$ & $\begin{array}{l}34 \pm 11^{\mathrm{b}} \\
37 \pm 12^{\mathrm{b}}\end{array}$ & $\begin{array}{l}73 \pm 16^{b} \\
69 \pm 11^{b}\end{array}$ \\
\hline $\begin{array}{l}\text { Heart rate } \\
\text { (beats/min) }\end{array}$ & $\begin{array}{l}\text { baseline } \\
\text { epinephrine }\end{array}$ & $\begin{array}{l}71 \pm 3 \\
73 \pm 3\end{array}$ & $\begin{array}{l}72 \pm 4 \\
78 \pm 7^{\mathrm{a}}\end{array}$ & $\begin{array}{l}73 \pm 2 \\
76 \pm 6^{a}\end{array}$ & $\begin{array}{l}70 \pm 3 \\
75 \pm 6\end{array}$ \\
\hline $\begin{array}{l}\text { Systolic BP } \\
(\mathrm{mm} \mathrm{Hg})\end{array}$ & $\begin{array}{l}\text { baseline } \\
\text { epinephrine }\end{array}$ & $\begin{array}{l}108 \pm 4 \\
105 \pm 4\end{array}$ & $\begin{array}{l}111 \pm 5 \\
116 \pm 8^{a, b}\end{array}$ & $\begin{array}{l}108 \pm 5 \\
115 \pm 7^{a, b}\end{array}$ & $\begin{array}{l}109 \pm 3 \\
110 \pm 4\end{array}$ \\
\hline $\begin{array}{l}\text { Diastolic BP } \\
(\mathrm{mm} \mathrm{Hg})\end{array}$ & $\begin{array}{l}\text { baseline } \\
\text { diastolic }\end{array}$ & $\begin{array}{l}75 \pm 4 \\
75 \pm 4\end{array}$ & $\begin{array}{l}73 \pm 6 \\
72 \pm 7\end{array}$ & $\begin{array}{l}72 \pm 4 \\
73 \pm 5\end{array}$ & $\begin{array}{l}75 \pm 3 \\
75 \pm 3\end{array}$ \\
\hline
\end{tabular}

${ }^{a}$ Statistically different from baseline (at least $p=0.05$ )

${ }^{b}$ Statistically different from control study (at least $p=0.05$ )

\section{Plasma catecholamine (Tables 1 and 2)}

In each study, in normal subjects as well as in Type 1 diabetic patients, baseline steady-state plasma epinephrine and norepinephrine concentrations were similar during the three different clamps. During exogenous epinephrine infusion, plasma epinephrine concentrations rose to the same extent in both normal and Type 1 diabetic subjects. Plasma epinephrine concentrations were similar between each study performed on the same patient.

\section{Plasma glucagon (Tables 1 and 2)}

In both normal and Type 1 diabetic subjects, exogenously replaced glucagon concentrations were similar to baseline hormone concentrations. No differences were appreciable between the two groups.

\section{NEFA concentration and palmitate kinetics}

(Figs. 2, 3, and 5)

In both normal subjects and Type 1 diabetic patients baseline NEFA concentrations, and palmitate rate of appearance ( $\mathrm{Ra}$ ) remained steady during the control study (Fig. 2). During the first clamp, in the epinephrinestimulated period, plasma NEFA increased from $238 \pm 22$
BP, Blood pressure; C-peptide $1 \mathrm{nmol} / \mathrm{l}=3.02 \mathrm{ng} / \mathrm{ml}$; Insulin $1 \mathrm{pmol} / \mathrm{l}=0.167 \mathrm{lU} / \mathrm{ml}$; Epinephrine $1 \mathrm{pmol} / \mathrm{l}=0.183 \mathrm{pg} / \mathrm{ml}$; Norepinephrine $1 \mathrm{nmol} / \mathrm{l}=169 \mathrm{pg} / \mathrm{ml}$; Glucagon $=1 \mathrm{ng} / \mathrm{l}=1 \mathrm{pg} / \mathrm{ml}$

to $529 \pm 58 \mu \mathrm{mol} / 1 \quad(p<0.01)$ in Type 1 diabetic patients. Palmitate $\mathrm{Ra}$ increased from $2.22 \pm 0.29$ to $4.38 \pm 0.47 \mu \mathrm{mol} \cdot \mathrm{kg}^{-1} \cdot \mathrm{min}^{-1}$. During epinephrine administration, in normal subjects, NEFA concentrations rose from a baseline of $203 \pm 22$ to $443 \pm 46 \mu \mathrm{mol} / \mathrm{l}$ $(p<0.01)$, with an increment from baseline (Fig.5) of $218 \pm 25 \%$ similar to that observed in Type 1 diabetic patients $(222 \pm 15 \%$, NS). Palmitate $\mathrm{Ra}$ rose from $1.87 \pm 0.23$ to $4.06 \pm 0.38 \mu \mathrm{mol} \cdot \mathrm{kg}^{-1} \cdot \min ^{-1} \quad(p<0.01)$. The increment from baseline was $217 \pm 22 \%$, - not significantly different to that observed in Type 1 diabetic patients $(197 \pm 25 \%)$.

During the second clamp, in Type 1 diabetic patients, NEFA rose from $153 \pm 27$ to $255 \pm 62 \mu \mathrm{mol} / 1(p<0.01)$. The increment of plasma NEFA from baseline during epinephrine administration was $166 \pm 23 \%$, - not statistically different from that observed in normal subjects $(130 \pm 16 \%)$. Palmitate $\mathrm{Ra}$ increased from $1.93 \pm 0.29$ to $3.00 \pm 0.43 \mu \mathrm{mol} \cdot \mathrm{kg}^{-1} \cdot \mathrm{min}^{-1}(p<0.01)$, but the percentage increment was not statistically different $(155 \pm 26 \%)$ from that observed in normal subjects in which palmitate $\mathrm{Ra}$ increased from $1.36 \pm 0.21$ to $2.37 \pm 0.25$ $\mu \mathrm{mol} \cdot \mathrm{kg}^{-1} \cdot \min ^{-1}(p<0.05)$ with an increment from baseline of $174 \pm 26 \%$.

During the third clamp, in the Type 1 diabetic patients, NEFA increased from $77 \pm 12$ to $117 \pm 29 \mu \mathrm{mol} / 1$ $(p<0.05)$, with a parallel increment of palmitate Ra from $0.84 \pm 0.31$ to $1.63 \pm 0.45 \mu \mathrm{mol} \cdot \mathrm{kg}^{-1} \cdot \mathrm{min}^{-1} \quad(p<0.05)$. The increment of plasma NEFA from baseline was 


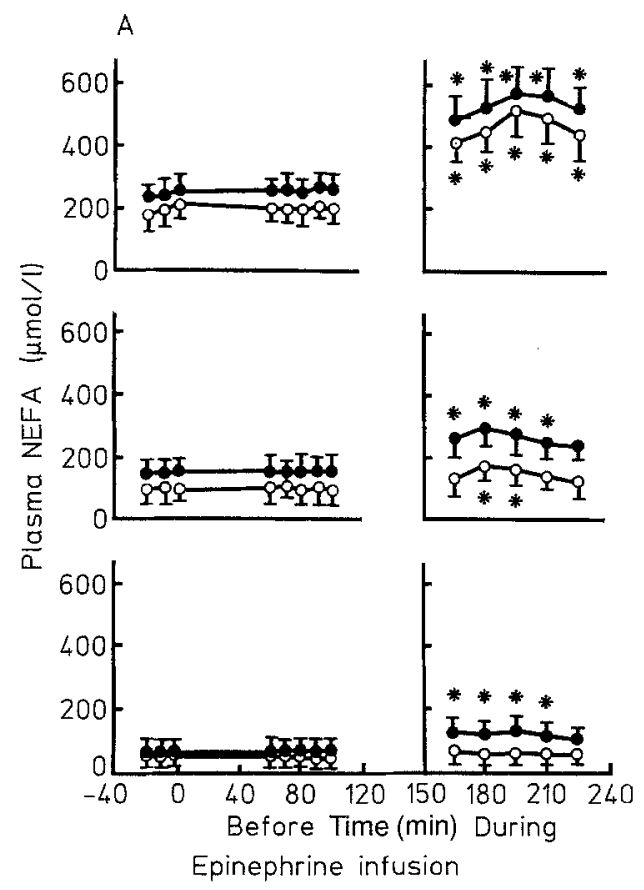

Fig.3A,B. A Mean ( \pm SEM) plasma NEFA concentration and $\mathbf{B}$ palmitic acid rate of appearance in blood plasma ( $\mathrm{Ra}$ ) during first clamp $\left(0.2 \mathrm{mU} \cdot \mathrm{kg}^{-1} \cdot \mathrm{min}^{-1}\right.$; upper panel), second clamp $(0.4 \mathrm{mU}$. $\mathrm{kg}^{-1} \cdot \mathrm{min}^{-1}$; middle panel), and third clamp $\left(0.8 \mathrm{mU} \cdot \mathrm{kg}^{-1} \cdot \mathrm{min}^{-1}\right.$;

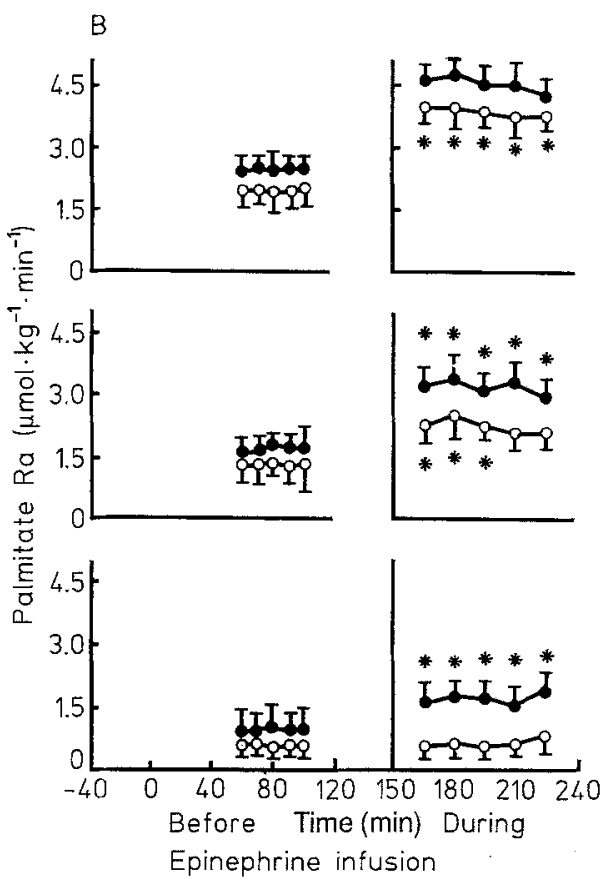

lower panel) before and during epinephrine infusion in normal subjects $(\mathrm{O}-\mathrm{O})$ and diabetic patients $(-)$. Asterisks: statistical significance between control and epinephrine stimulated periods

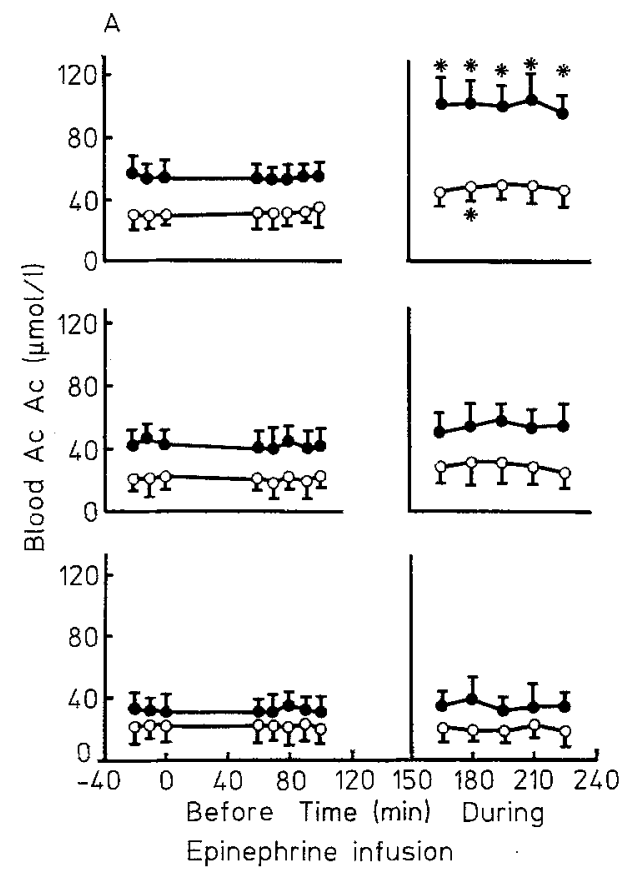

Fig. 4A,B. A Mean ( \pm SEM) blood acetoacetate (AcAc) concentration and $\mathbf{B}$ rate of appearance ( $\mathrm{Ra}$ ) in blood plasma during first clamp $\left(0.2 \mathrm{mU} \cdot \mathrm{kg}^{-1} \cdot \mathrm{min}^{-1}\right.$; upper panel $)$, second clamp $(0.4 \mathrm{mU}$. $\mathrm{kg}^{-1} \cdot \mathrm{min}^{-1}$; middle panel) and third clamp $\left(0.8 \mathrm{mU} \cdot \mathrm{kg}^{-1} \cdot \mathrm{min}^{-1}\right.$;

$151 \pm 13 \%$, significantly different from that observed during the third clamp in normal control subjects, in whom NEFA did not change during epinephrine administration. Similarly, in Type 1 diabetic patients, the increment of palmitate $\mathrm{Ra}$ from baseline was significantly higher $(194 \pm 21 \%, p<0.05)$ than in normal control subjects.

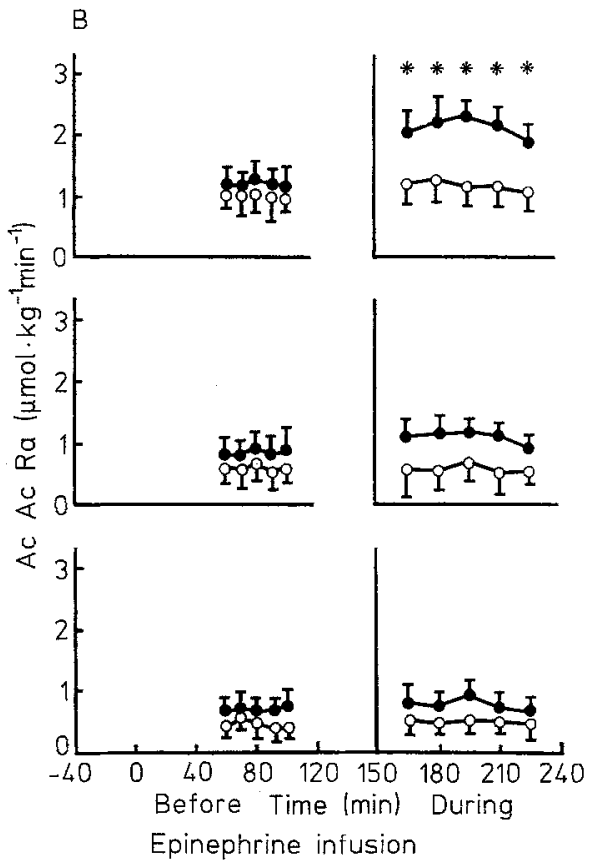

lower panel) before and during epinephrine infusion in normal subjects $(0-0)$ and in diabetic patients $(\longrightarrow)$. Asterisks: statistical significance between control and epinephrine stimulated periods

Blood $K B$ concentration and kinetics (Figs. 2, 4, 5, and 6)

During the control study, in Type 1 diabetic patients, baseline AcAc and 3-BOH concentrations and their rate of disappearance remained steady throughout the study (Fig. 2). 


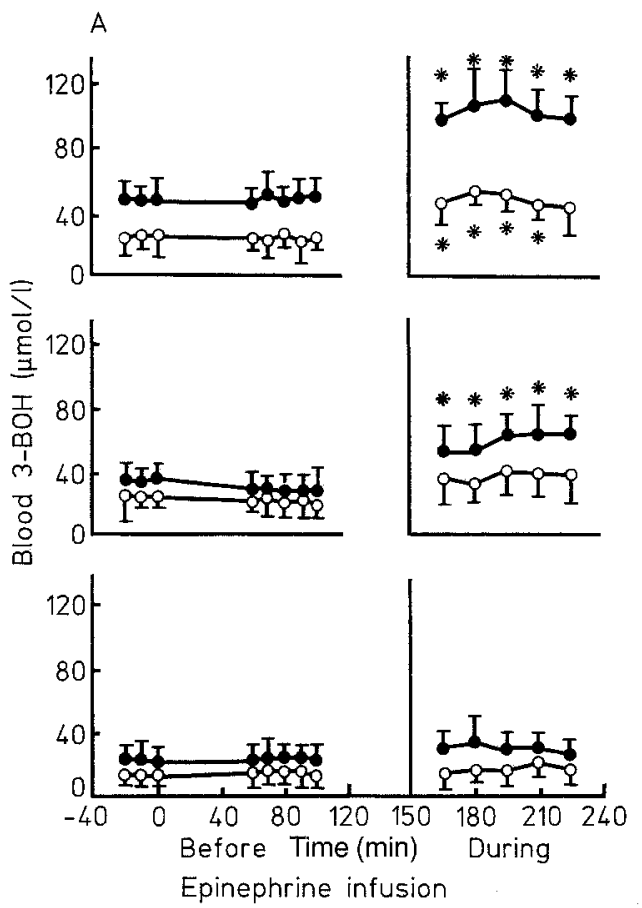

Fig.5A,B. A Mean ( \pm SEM) blood 3-hydroxybutyrate (3-BOH) concentration and $\mathbf{B}$ rate of appearance in blood plasma $(\mathrm{Ra})$ during the first clamp $\left(0.2 \mathrm{mU} \cdot \mathrm{kg}^{-1} \cdot \mathrm{min}^{-1}\right.$; upper panel $)$, second clamp $\left(0.4 \mathrm{mU} \cdot \mathrm{kg}^{-1} \cdot \mathrm{min}^{-1}\right.$; middle panel $)$, and third clamp

During the first clamp, epinephrine administration to diabetic patients increased AcAc concentrations from $59 \pm 10$ to $97 \pm 24 \mu \mathrm{mol} / 1(p<0.05)$, and AcAc Ra from $1.15 \pm 0.13$ to $2.16 \pm 0.75 \mu \mathrm{mol} \cdot \mathrm{kg}^{-1} \cdot \min ^{-1} \quad(p<0.05)$. During the second clamp, neither AcAc concentrations $(46 \pm 8$ to $58 \pm 11 \mu \mathrm{mol} / 1 ; \mathrm{NS})$ nor $\mathrm{AcAc} \mathrm{Ra}(0.81 \pm 0.18$ to $1.12 \pm 0.27 \mu \mathrm{mol} \cdot \mathrm{kg}^{-1} \cdot \mathrm{min}^{-1}$; NS) changed significantly. Similarly, during the third clamp, neither AcAc concentrations nor Ra changed during epinephrine infusion. In normal subjects, during the three different clamps, AcAc concentrations and Ra did not change significantly from the baseline concentration during epinephrine infusion.

In both normal subjects and Type 1 diabetic patients, 3-BOH concentrations did not change throughout the control study. During the first clamp, in Type 1 diabetic patients, both 3-BOH concentrations (from $51 \pm 9$ to $100 \pm 15 \mu \mathrm{mol} / / ; \quad p<0.05$ ) and 3-BOH Ra (from $1.07 \pm 0.23$ to $\left.2.09 \pm 0.57 \mu \mathrm{mol} \cdot \mathrm{kg}^{-1} \cdot \mathrm{min}^{-1} ; p<0.05\right)$ increased during epinephrine infusion.

During the second clamp, 3-BOH concentrations rose from $36 \pm 5$ to $67 \pm 14 \mu \mathrm{mol} / /(p<0.05)$, with a parallel increment of $3-\mathrm{BOH} \mathrm{Ra}$ from $0.62 \pm 0.27$ to $1.43 \pm$ $0.48 \mu \mathrm{mol} \cdot \mathrm{kg}^{-1} \cdot \min ^{-1} \quad(p<0.05)$. During the third clamp, neither $3-\mathrm{BOH}$ concentrations $(28 \pm 5$ to $35 \pm$ $7 \mu \mathrm{mol} / 1$; NS), nor $3-\mathrm{BOH}$ Ra $(0.52 \pm 0.15$ vs $0.61 \pm$ $0.23 \mu \mathrm{mol} \cdot \mathrm{kg}^{-1} \cdot \mathrm{min}^{-1}$ ) changed during epinephrine infusion.

During the first clamp, in normal subjects, $3-\mathrm{BOH}$ concentrations ( $34 \pm 6$ to $53 \pm 16 \mu \mathrm{mol} / 1 ; p<0.05$ ) and $3-\mathrm{BOH}$ $\mathrm{Ra}$ (from $0.73 \pm 0.08$ to $1.36 \pm 0.21 \mu \mathrm{mol} \cdot \mathrm{kg}^{-1} \cdot \mathrm{min}^{-1}$; $p<0.05)$ increased during epinephrine infusion. During the second clamp, neither 3-BOH concentration (from $28 \pm 7$ to $39 \pm 12 \mu \mathrm{mol} / \mathrm{l} ; \mathrm{NS}$ ), nor $3-\mathrm{BOH}$ changed under
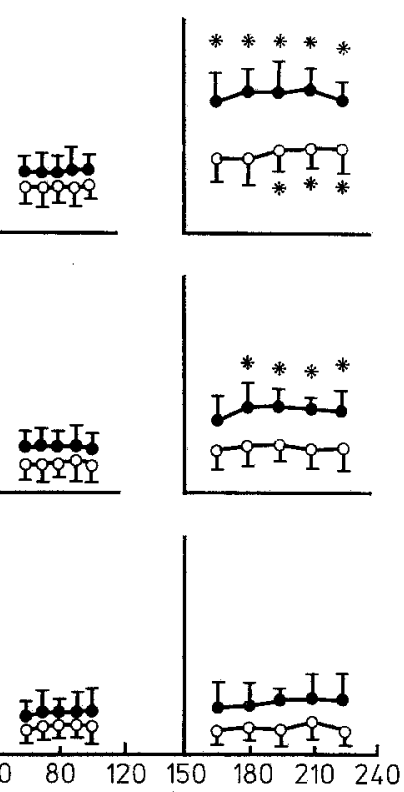

efore Time(min) During

Epinephrine infusion

$\left(0.8 \mathrm{mU} \cdot \mathrm{kg}^{-1} \cdot \mathrm{min}^{-1}\right.$; lower panel) before and during epinephrine infusion in normal subjects $(\mathrm{O}-\mathrm{O})$ and diabetic patients $(-)$ ). Asterisks: statistical significance between control period and epinephrine stimulated periods

epinephrine stimulation. Similarly, during the third clamp, neither 3-BOH concentration nor 3-BOH Ra changed significantly during epinephrine administration. During the first clamp, in Type 1 diabetic patients, under epinephrine challenge, the increment of blood total $\mathrm{KB}$ (AcAc +3$\mathrm{BOH})$ concentrations from baseline was significantly higher than that observed in normal subjects $(179 \pm 14 \%$ vs $155 \pm 9 \% ; p<0.05)$, whereas it was not significantly different during the second ( $156 \pm 19 \%$ vs $148 \pm 16 \%$; NS) and third clamps ( $125 \pm 18 \%$ vs $107 \pm 19 \%$; NS). Similar$1 y$, the increment of blood total KB Ra from baseline during epinephrine infusion was significantly higher in Type 1 diabetic patients than in normal subjects during the first clamp ( $189 \pm 16 \%$ vs $142 \pm 13 \% ; p<0.05)$. During the second, under epinephrine challenge, the increment of total $\mathrm{KB}$ was again significantly higher in Type 1 diabetic patients $(178 \pm 21 \%$ vs $131 \pm 17 \% ; p<0.05)$ than in normal subjects, whereas it was not significant during the third clamp ( $106 \pm 17 \%$ vs $116 \pm 19 ;$ NS $)$.

\section{Discussion}

The purpose of this study stemmed from the observation that, in both normal subjects and in Type 1 diabetic patients, in contrast to the glycaemic response, endogenous insulin secretion does not normally limit the lipolytic and ketogenetic responses of epinephrine infusion [12]. Data on the interplay between the insulin and adrenergic system, as far as lipolysis is concerned, are available from in vitro studies $[9,10]$ in which increased insulin concentrations have been shown to prevent the lipolytic action of epinephrine. This study confirms that epinephrine possesses 

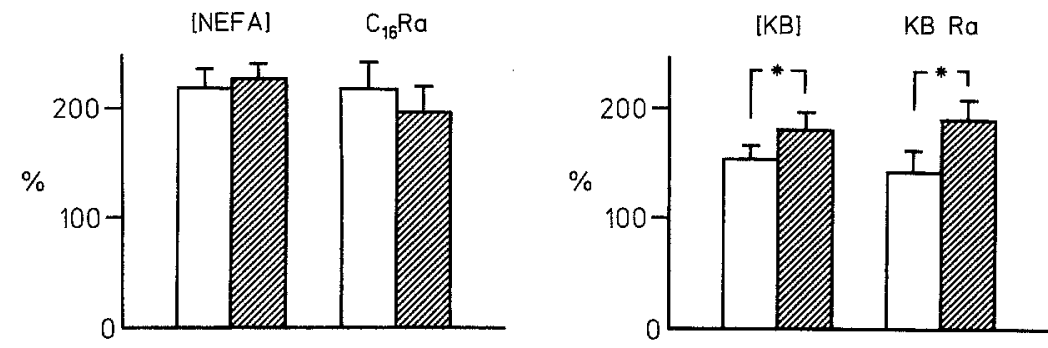

$0.2 \mathrm{mU} \cdot \mathrm{kg}^{-1} \cdot \mathrm{min}^{-1}$
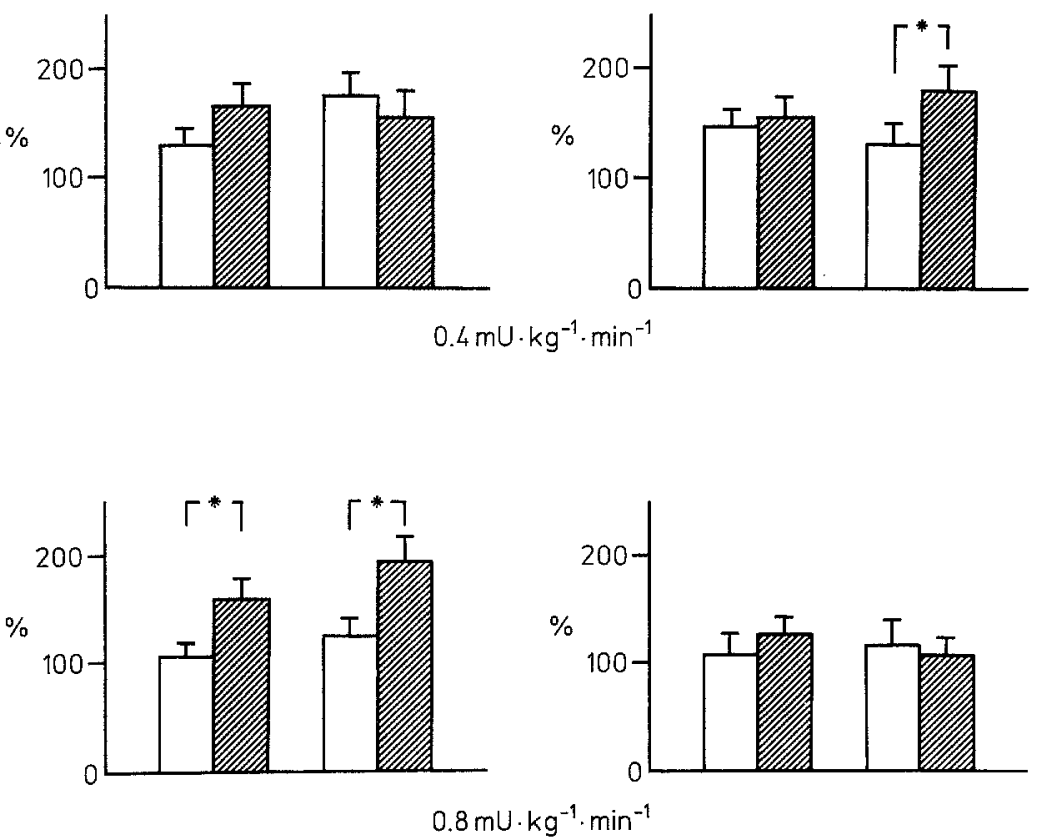

Fig.6. Mean ( \pm SEM) percentage increments from baseline during epinephrine infusion of plasma nonesterified fatty acid concentration ([NEFA]), palmitate rate of appearance (C16 Ra), blood ketone body $(\mathrm{AcAc}+3-\mathrm{BOH})$ concentration $([\mathrm{KB}])$, and ketone body tate of appearance (KB Ra). Normal subjects $\square$; Type 1 (insulin-dependent) diabetic patients $\mathscr{Z}$. Asterisks: significant differences between Type 1 diabetic patients and normal subjects. $100 \%$ indicates no change from baseline value

both lipolytic and an overall ketogenic effect, in accordance with previous works by Weiss et al. [30] and Smith et al. [31]. However, our data are at variance with the findings of Beylot et al. [32] who found an anti-ketogenic effect of epinephrine [32]. One plausible reason for this discrepancy between our and their data may be that they failed to suppress endogenous insulin secretion during epinephrine infusion, and hence could not separate the direct and indirect effects that high plasma epinephrine concentrations have on glucose and lipid metabolism.

This is the first study in which the effects of epinephrine on lipolysis and ketogenesis are simultaneously examined by means of the contemporary administration of stable labelled NEFA and KB. It should be emphasized that the $\left[{ }^{13} \mathrm{C}_{1}\right]$ palmitate tracer used in this study measures net lipolysis rather than total lipolysis. However, ${ }^{13} \mathrm{C}_{1}$ palmitate did allow us to assess the kinetics of NEFA and hence of net lipolysis, which is the primary determinant of KB production in the liver.

This study shows that, during insulin infusion at the rate of $0.2 \mathrm{mU} \cdot \mathrm{kg}^{-1} \cdot \mathrm{min}^{-1}$, even though the values of absolute NEFA concentration and rate of appearance were higher in Type 1 diabetic patients, their lipolytic response to epinephrine in Type 1 diabetic patients was of com- parable magnitude to that observed in normal subjects. Despite the similar lipolytic response, the overall ketogenetic response to epinephrine was increased in diabetic subjects. This observation confirms that the absence of insulin secretion plays a major role in enhancing lipolytic and ketogenic responses in such patients, and supports the hypothesis that at least at low insulin concentrations, for a given inflow of NEFA in the liver, Type 1 diabetic patients are capable of producing a higher amount of $\mathrm{KB}$ [33]. This greater ketogenic response to epinephrine stimulation in diabetic patients may be due to the hepatic insulin resistance induced by the peculiar hormonal milieu of these subjects. This hypothesis is supported by previous reports which showed that, during conventional insulin treatment, Type 1 diabetic patients, have increased concentrations of counterregulatory hormones such as growth hormone [34] and cortisol [35]. These hormones may make the liver more "susceptible" to the ketogenic action of epinephrine, despite euglycaemia.

Another possibility is a breakthrough of insulin secretion induced by hyperglycaemia during epinephrine challenge in normal subjects, despite somatostatin infusion. However, in our experimental setting, plasma glucose was always below $10 \mathrm{mmol} / \mathrm{l}$ which is the threshold con- 
centration at which this phenomenon is usually observed [36].

At intermediate insulin concentrations there is a similar significant lipolytic effect of epinephrine in both control and in Type 1 diabetic patients: however, a significant response of the $\mathrm{KB}$ rate of appearance (3-BOH) was observed only in diabetic patients. When plasma free insulin concentration is raised to $80 \mathrm{mU} / \mathrm{l}$, there is complete inhibition of epinephrine-stimulated ketogenesis in both normal and Type 1 diabetic subjects. However, it is interesting to note that there is still a distinct lipolytic response to epinephrine in diabetic subjects. This suggests, as shown by Keller et al. [37] that high plasma insulin concentrations inhibit ketogenesis not only by decreasing the NEFA supply to the liver, but probably also by directly restricting $\mathrm{KB}$ formation at the site of production.

The persistent lipolytic effects despite high insulin concentrations observed here in Type 1 diabetic patients, may be explained not only by the increased responsiveness of adipocytes to epinephrine in this population [11] but also by insulin resistance. In this regard, Jensen and colleagues [38] showed that the antilipolytic effect of insulin is diminished in diabetic patients and that this defect in hormone action seems to be due to reduced insulin sensitivity.

Unfortunately, limited information is available on ketogenic responsiveness to epinephrine in Type 1 diabetic patients with poor metabolic control. To our knowledge, the only data available are those of Keller [39] and Weiss [40] in insulin-deficient subjects. These authors have shown that total insulin deficiency augments the stimulatory effect of norepinephrine and epinephrine on hepatic ketogenesis, probably due to a greater intrahepatic conversion of NEFA to KB.

In our experimental setting, caution should be paid to the fact that the baseline fatty acid concentration may have altered the lipolytic response of NEFA to epinephrine in the various studies. Furthermore, recent experimental data suggest that somatostatin increases clearance of NEFA [41]. This may have some effect on ketogenesis as well, although there is no evidence that it has similar effects in humans. Our diabetic subjects received prolonged infusion of insulin prior to the clamp study. Its potential effects on re-esterification, and on hepatic sensitivity to NEFA disposal to $\mathrm{CO}_{2}$, ketones, or triglycerides may have been influenced.

Another aspect of our study which we believe deserves comment is the glycaemic response to epinephrine. Increased insulin secretion, albeit restricted normally limits the glycaemic response. Instead, at high insulin concentrations such as those obtained during the $0.8 \mathrm{mU} \cdot \mathrm{kg}^{-1}$. $\min ^{-1}$ infusion rate, we found a still distinct glycaemic response in spite of reduced lipolytic and ketogenic responses. This indicates that increased plasma insulin levels are able to restrict but unable to abolish completely the glycaemic response to high epinephrine concentrations. In our experimental setting, we cannot rule out the direct effect of an increased plasma glucose concentration on lipolysis, because, during epinephrine infusion, plasma glucose concentration can no longer be clamped. In this regard, it has recently been shown that hyperglycaemia has a direct antilipolytic effect and the fact that this hyperglycaemia may have affected the ketogenic and lipolytic responses to epinephrine cannot be excluded [42]. However, this observation on the whole provides additional evidence as to how the adrenergic system ensures an adequate glucose supply even in the presence of high circulating insulin levels which are usually able to significantly decrease other oxidizable substrates such as ketones.

In conclusion, this study shows that high insulin levels are able to restrict the ketogenic reaction to epinephrine challenge in both normal and Type 1 diabetic subjects. In the latter the ketogenic response is blunted, despite a detectable lipolytic response. In the presence of a plasmafree insulin level that completely restricts the ketogenic response, there is still a distinct glycaemic response. Plasma insulin levels in Type 1 diabetic subjects seem to be a major determinant of the metabolic consequence of stress.

Acknowledgements. This study was supported by Progetto finalizzato CNR N. 9100446.PF 40. AA thanks Ms. C. Walton for the invaluable linguistic support.

\section{References}

1. Avogaro A, Nosadini R, Doria A et al. (1990) Substrate availability other than glucose in the brain during euglycemia and insulin induced hypoglycemia in dogs. Metabolism 39:46-50

2. Avogaro A, Nosadini R, Doria A et al. (1990) Myocardial metabolism in insulin-deficient diabetic humans without coronary artery disease. Am J Physiol 258: E606-E618

3. Nosadini R, Avogaro A, Trevisan R et al. (1985) Acetoacetate and 3-hydroxybutyrate kinetics in obese and insulin dependent diabetic humans. Am J Physiol 248: R611-R620

4. Pardridge WH (1983) Brain metabolism from the blood brain barrier. Physiol Rev 63: 1481-1535

5. McGarry JD, Foster DW (1980) Regulation of hepatic fatty acid oxidation and ketone body production. Ann Rev Biochem 49: 395-420

6. Fain JN, Garcia-Sainz JA (1983) Adrenergic regulation of adipocyte metabolism. J Lipid Res 24: 945-966

7. Shechter Y, Reitman P, Hizi A (1982) Evaluation of factors responsible for the inability of insulin to antagonize lipolysis due to high concentrations of catecholamine. Biochem Biophys Res Commun 109: 776-785

8. Engfeldt P, Hellmer J, Wahrenberg H, Arner P (1988) Effects of insulin on adrenoceptor binding and the rate of catecholamineinduced lipolysis in isolated human fat cells. J Biol Chem 263: 15553-15560

9. Abumrad NA, Harmon CM, Barnela US, Whitesell RR (1988) Insulin antagonism of catecholamine stimulation of fatty acid transport in the adipocytes. J Biol Chem 263: 14678-14683

10. Abumrad NA, Perry PR, Whitesell RR (1986) Insulin antagonizes epinephrine activation of the membrane transport of fatty acids. Potential site for hormonal suppression of lipid mobilization. J Biol Chem 261:2999-3001

11. Wahrenberg H, Lonnqvist F, Engfeldt P, Arner P (1989) Abnormal action of catecholamine on lipolysis in adipocytes of type I diabetic patients treated with insulin. Diabetes 38: 524-533

12. Berk MA, Clutter WE, Skor D et al. (1985) Enhanced glycemic responsiveness to epinephrine in insulin dependent diabetes mellitus is the result of the inability to secrete insulin. Augmented insulin secretion normally limits the glycemic, but not the lipolytic or ketogenetic response to epinephrine in humans. J Clin Invest 75: 1842-1851 
13. Lager I, Attval S, Eriksson BM, von Schenk H, Smith U (1986) Studies on the insulin antagonistic effect of catecholamines in normal man. Diabetologia 29:409-416

14. Rowe JW, Young JB, Minaker KL, Stevens AL, Pallotta J, Landsberg L (1981) Effect of insulin and glucose infusions on sympathetic nervous system activity in normal man. Diabetes 30 : 219-225

15. Bougneres PF, Bier DM (1982) Stable isotope dilution method for measurement of palmitate content and labeled palmitate tracer enrichment in microliter plasma samples. J Lipid Res 23: 502-507

16. Cobelli C, Nosadini R, Toffolo G et al. (1982) Model of the kinetics of ketone bodies in humans. Am J Physiol 243: R7-R17

17. Nosadini R, Avogaro A, Sacca' L et al. (1985) Ketone body metabolism in normal and diabetic human skeletal muscle. Am J Physiol 249: E131-E136

18. Clutter WE, Bier DM, Shah SD, Cryer PE (1980) Epinephrine plasma metabolic clearance rates and physiologic thresholds for metabolic and hemodynamic action in man. J Clin Invest 66: 94101

19. Lloyd B, Burrin J, Smythe P, Alberti KGMM (1978) Enzymic fluorometric continuous flow assays for blood glucose, lactate, pyruvate, alanine, glycerol, and 3-hydroxybutyrate. Clin Chem. 34: $1727-1729$

20. Bougneres PF, Karl IE, Hillman LS, Bier DM(1982) Lipid transport in the human newborn: palmitate and glycerol turnover and the contribution of glycerol to hepatic glucose output. J Clin Invest 70: $262-270$

21. Hagenfeldt L (1966) A gas chromatographic method for the determination of individual free fatty acids in plasma. Clin Chim Acta 13: 266-268

22. Avogaro A, Bier DM (1989) Contribution of 3-hydroxyisobutyrate to the measurement of 3-hydroxybutyrate in human plasma: comparison of enzymatic and gas chromatography-mass spectrometry assays in normal and diabetic subjects. J Lipid Res 30: 1811-1817

23. Hyemdahl P (1984) Catecholamine measurements by high performance liquid chromatography. Am J Physiol 247: E13-E20

24. Schalch D, Parker M (1964) A sensitive double antibody radioimmunoassay for growth hormone in plasma. Nature 203: $1141-1142$

25. Kuzuya H, Blix PM, Horwitz DL, Steiner DF, Rubenstein AH (1977) Determination of free and total insulin and C-peptide in insulin treated diabetics. Diabetes 26:22-29

26. Ensick JW (1983) Immunoassay for glucagon. In: Lefebvre $P$ (ed) Glucagon. Handbook of experimental pharmacology, Vol. 66. Springer, New York, pp 203-221

27. Jensen MD, Heiling V, Miles JM (1990) Measurement of non steady state free fatty acid turnover. Am JPhysiol 258:E103-E108

28. Cobelli C, Toffolo G, Bier DM, Nosadini R (1987) Models to interpret kinetic data in stable isotope tracer studies. Am J Physiol 253: E551-E564

29. Keller U, Sonnenberg GE, Stauffacher W (1981) Validation of a tracer technique to determine nonsteady state ketone body turnover rates in man. Am J Physiol E253-E262
30. Weiss M, Keller U, Stauffacher W (1984) Effects of epinephrine and somatostatin induced insulin deficiency on ketone body kinetics and lipolysis in man. Diabetes 33: 738-744

31. Smith U, Lager I (1989) Insulin antagonistic effects of counterregulatory hormones: clinical and mechanistic aspects. Diab Metab Rev 5: 511-525

32. Beylot M, Beaufrere B, Riou JP et al. (1987) Effect of epinephrine on the relationship between nonesterified fatty acid availability and ketone body production in postabsorptive man: evidence for a hepatic antiketogenetic effect of epinephrine. J Clin Endocrinol Metab 65: 914-921

33. Nosadini R, Avogaro A, Doria A, Fioretto P, Trevisan R, Morocutti A (1989) Ketone body metabolism: a physiological and clinical overview. Diab Metab Rev 5:299-319

34. Press M, Tamborlane WV, Sherwin RS (1984) Importance of raised growth hormone levels in mediating the metabolic derangements of diabetes. N Engl J Med: $310,810-815$

35. MacGillivray MH, Li PK, Lee JT et al. (1982) Elevated plasma $\beta$-hydroxybutyrate concentrations without ketonuria in healthy insulin-dependent diabetic patients. J Clin Endocrinol Metab 54: 665-668

36. Caruso M, Divertie GD, Jensen MD, Miles JM (1990) Lack of effect of hyperglycemia on lipolysis in humans. Am J Physiol 259: E542-E547

37. Keller U, Gerber PPG, Stauffacher W (1988) Fatty acid independent inhibition of hepatic ketone body production by insulin in humans. Am J Physiol 254: E694-E699

38. Jensen MD, Caruso M, Heiling V, Miles JM (1989) Insulin regulation of lipolysis in nondiabetic and IDDM subjects. Diabetes 38: 1595-1601

39. Keller U, Gerber PG, Stauffacher W (1984) Stimulatory effect of norepinephrine on ketogenesis in normal and insulin-deficient humans. Am J Physiol 247: E732-E739

40. Weiss M, Keller U, Stauffacher W (1984) Effect of epinephrine and somatostatin-induced insulin deficiency on ketone body kinetics and lipolysis in man. Diabetes 33: 738-744

41. Strosser MT, Scala-Gvenot DD, Koch B, Mialhe P (1983) Inhibitory effect and mode of action of somatostatin on lipolysis in chicken adipocytes. Biochim Biophys Acta 763: 191-196

42. Park KS, Rhee BD, Lee KU, Lee HK, Koh CS, Min HK (1990) Hyperglycemia per se can reduce plasma free fatty acid and glycerol levels in acutely insulin deficient dog. Metabolism 39: 595-597

Received: 9 April 1991

and in revised form: 25 September 1991

Dr. A. Avogaro

Cattedra di Malattie del Ricambio

Via Giustiniani 2

I-35100 Padova

Italy 